\section{Against Empathy: the Case for Rational} Compassion

Paul Bloom

Bodley Head, 2017, HB, 304pp, E18.99, 9781847923141

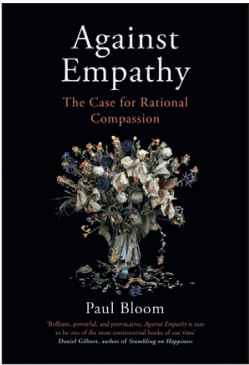

\section{FORMING A BRIDGE}

At first glance, presenting an argument against empathy seems counterintuitive. However, Bloom's argument is against a narrowly defined form of empathy restricted to the affective domain.

Much of the research and debate around empathy is hampered by the muddle surrounding the definition of this nuanced concept and this book adds to this conceptual confusion. The author's concept of empathy is more aligned to sympathy, which is linked to causing personal distress and burnout. His subtitle to the book 'Rational Compassion', which he supports, is attuned with current thinking on empathy as a broad concept that has cognitive, affective, moral, and behavioural aspects.

Bloom adopts a utilitarian approach to ethics and empathy, which many doctors may find difficult to reconcile with their clinical practice. Empathy in clinical medicine involves individuals in a face-to--face encounter; it is a relational concept. Bloom argues that, because empathy may be biased towards people we like, it is not a force for moral good. Many might argue that empathy attempts to be non-judgemental and forms a bridge across cultural and ethnic divisions.

Empathy is not simply a cognitive or an affective phenomenon, but a combination of the two in varying amounts according to the clinical situation. Bloom's controversial title and ethos on empathy may be more relevant to the current politics in the US than to medical practice in this country.

\section{David Jeffrey,}

Honorary Lecturer in Palliative Medicine and PhD student, Department of Primary Palliative Care, University of Edinburgh, Medical School, Teviot Place, Edinburgh.

E-mail: D.I.Jeffreyßिsms.ed.ac.uk
DOI: https://doi.org/10.3399/bjgp17X692921

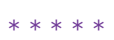

\section{The Fatal Tree \\ Jake Arnott}

Sceptre, Hodder \& Stoughton, 2017, PB, 352pp, E8.99, 978-1473637764

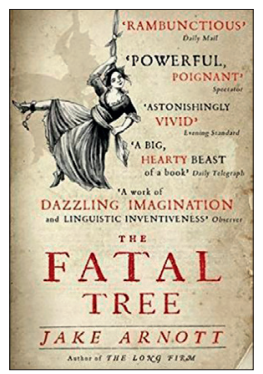

\section{A PRACTICAL GUIDE TO 18TH-CENTURY CRIMINALITY}

With general practice being such a busy profession, at present it's difficult to find the time to do all those other things you've been meaning to do. Reading more books, learning a language, satisfying an amateur historical interest - they've all had to be put on the back burner. However, with Jake Arnott's new novel The Fatal Tree it may be possible to achieve all three during a short holiday.

The 'fatal tree' of the title refers to the gallows at Tyburn, the final destination of many of the characters who belong to the criminal underworld of 1720 s London. They are members of the slang-speaking 'canting crew' and, with the help of the glossary, you too will prattle flash (speak slang) like a rum prig (good thief) within a couple of chapters.

Some of these criminals were the celebrities of the age, their final confessions ghostwritten by Daniel Defoe and life stories dramatised for the stage. Arnott however takes the rare step of writing the story of a woman - Elizabeth Lyon, alias 'Edgworth Bess', close associate of the great thief-taker Jonathan Wild and wife of the famous jailbreaker Jack Sheppard.

Hers was an untold story, but one, as a GP in modern times, that still rings true. We often meet young women who, having lost parental guidance and protection in their teens, made choices that put them in dangerous and exploitative situations. We also see the effect of a financial crash on the poorest in society - be it the credit crunch or the South Sea Bubble. Arnott's attention to the loves and vulnerabilities of Bess mean that, despite all her crimes and exploitation of others, it is very hard not to take her side.

Not only do the themes reach into today's world, but also, if you care to visit the Hunterian Museum, you can stand next to her associate Jonathan Wild. After his execution he suffered the fate most feared by the canting crew - to fall into the hands of surgeons. He was dissected and his skeleton is still on display today.

Jacqueline Harris,

GP Partner, Meadowcroft Surgery, Aylesbury.

E-mail: jacquelineharris1anhs.net

DOI: https://doi.org/10.3399/bjgp17X692933

$$
* * * * *
$$

The Ten Types of Human: a New Understanding of Who We Are, and Who We Can Be Dexter Dias

William Heinemann, 2017, HB, 848pp, E25.00, 978-1785150166

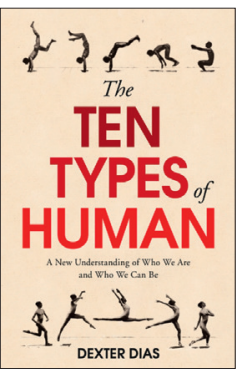

\section{THE NEED FOR COMPASSIONATE KINDNESS}

Dias has looked at the 'ten types of human' in his quest to understand the human mind. He believes it must have evolved in the same way the human body evolved and adapted, and in this first part he deals with what he calls the perceiver of pain. The thread that runs through this is the story of Anthony, a child sold to the slave trade in Africa, although he also looks at various areas of research into brain function and our ability to detect emotion. He asks, Why do we try to save the drowning child and how do we choose between a group of children and one of our own? Do we perceive children in other countries differently? Do we have a protective mechanism against too much pain we can't control?' He senses that we all perceive the pain of others but, as the numbers become greater, our system is unable to cope, so switches off, hence 'burnout'. He finds compassion reduces this. 
My take home from this is that we perceive and empathise with the suffering of others, but feel the pain ourselves. However, if we return this with compassionate kindness, this eases our own pain. As doctors, if we give compassionate care, we are better able to cope. Tickbox medicine is not a good thing for either patients or doctors.

\section{Natasha Usher,}

GP, Monifieth, Meigle, Angus, Dundee.

E-mail: natashađandrewusher.com

DOl: https://doi.org/10.3399/bjgp17X692945

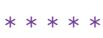

The Tidal Zone

\section{Sarah Moss}

Granta, 2016, PB, 336pp, E7.49, 9781783783076

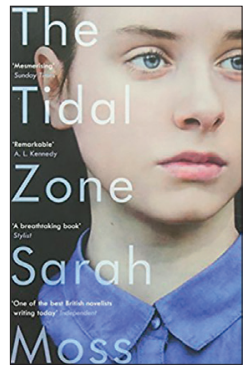

\section{LIFE AND DEATH, PARENTAL LOVE, GENDER POLITICS, AND THE NHS}

I've always believed that doctors and medical students have much to learn from works of fiction, and here is a case in point.

Sarah Moss has boldly adopted the firstperson narrative voice of a stay-at-home father, Adam, who is married to workaholic
GP Emma. They have two daughters, 8-yearold Rose and her 15-year-old sister Miriam. Miriam has had a few episodes of wheezing, but one day, on the playing field at school, she has a cardiac arrest, is resuscitated, and taken into hospital.

The book explores the effect of this crisis and its aftermath on the whole family, emphasising the anguish of uncertainty. Adam is desperate to know what caused the incident, whether it might recur, and what can be done to lessen the risk; his wife's professional knowledge that there may never be any clear answers is of little reassurance, nor does it do much for their increasingly strained relationship.

The attitudes and communication skills of the hospital staff range from empathy to (all too believable) crass dismissiveness, and it is here that Adam's perspective has much to teach us. For the staff, Miriam is one case among an ever-moving procession of patients; for Adam and the rest of the family, she is uniquely precious. And for doctors, uncertainty is endemic. For Adam it is terrifying. When the time comes for Miriam to be discharged her parents dread taking her away from the perceived safety of the hospital environment, and it takes months for them to let her resume anything like a normal life. Set against the trauma that his own family is going through, Adam constantly reminds himself - and us - that for much of the world's population fear, illness, disease, disaster, and death are the backdrop of daily existence.

Aside from the unfolding medical drama, the novel explores a number of other themes. Adam's wry, and often funny, observations about his role as the main childcarer will resonate with anyone in a similar position. In a scene both painful and comical, Adam escorts his younger daughter to a party at a swimming pool and finds himself shunned as a suspected paedophile. He harbours a suspicion that his wife's devotion to her patients and her work might actually be the easier role in their marriage. He has some part-time work in the university as an architectural historian, and we learn a lot about the genesis and construction of the new Coventry Cathedral. Miriam's acerbic conversation contributes an entertaining running commentary on the hypocrisies, outrages, and sheer ghastliness of what she might call our late-capitalist consumerist society. By contrast, Adam's father, a JewishAmerican ex-hippy, offers wisdom through his experience of living for many years in a series of 'intentional communities' (what used to be called communes), including the one in Cornwall in which Adam himself was raised. At times these threads jostle awkwardly with each other, but there is such richness in them all that it hardly matters.

Ultimately, this book is about the vulnerability and unpredictability of human life, and about confronting the unexpected.

Adam tells his story, but concludes:

'Stories have endings; that's why we tell them, for reassurance that there is meaning in our lives. But like a diagnosis, a story can become a prison, a straight road mapped out by the people who went before. Stories are not the truth.

Maybe so, but this one at least contains many truths.

Dougal Jeffries,

Retired GP, Cornwall.

E-mail: dougal6Ragmail.com

DOI: https://doi.org/10.3399/bjgp17X692885

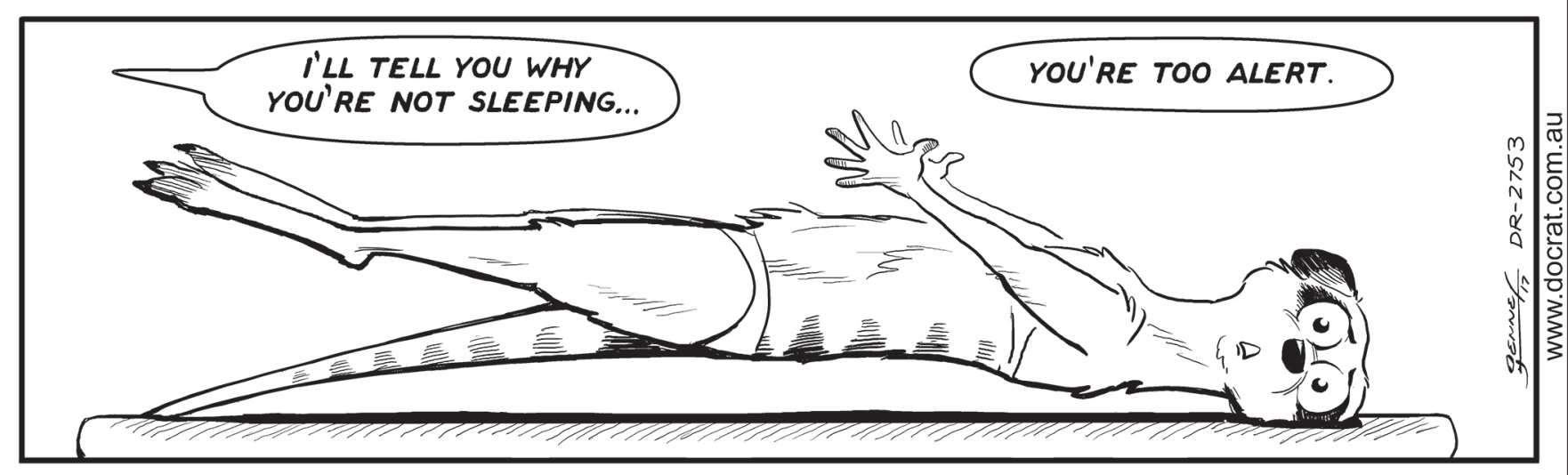

